PLANTS PEOPLE

POSSIBILITIES

\title{
Diospyros Ebenaster
}

\section{Author(s): M. B. Scott}

Source: Bulletin of Miscellaneous Information (Royal Botanic Gardens, Kew), Vol. 1915, No. 2 (1915), pp. 65-67

Published by: Springer on behalf of Royal Botanic Gardens, Kew

Stable URL: http://www.jstor.org/stable/4107492

Accessed: 27-06-2016 02:43 UTC

Your use of the JSTOR archive indicates your acceptance of the Terms \& Conditions of Use, available at

http://about.jstor.org/terms

JSTOR is a not-for-profit service that helps scholars, researchers, and students discover, use, and build upon a wide range of content in a trusted digital archive. We use information technology and tools to increase productivity and facilitate new forms of scholarship. For more information about JSTOR, please contact support@jstor.org.

Royal Botanic Gardens, Kew, Springer are collaborating with JSTOR to digitize, preserve and extend access to Bulletin of Miscellaneous Information (Royal Botanic Gardens, Kew) 
ROYAL BOTANIC GARDENS, KEW.

B ULLETIN

OF

\title{
MISCELLANE0US INF0RMA'TION.
}

No. 2]

\section{IV.-DIOSPYROS EBENASTER.}

\author{
M. B. Scotт.
}

Diospyros Ebenaster, Retz. is a widely cultivated tree, and is recorded from various botanic gardens in different parts of the world, but the information concerning its natural habitat is often contradictory and apparently inexact or incomplete. The object of these notes is to attempt to remove the confusion which has naturally arisen from such conflicting data, and to determine if possible the natural home of the plant.

Blanco in his "Flora de Filipinas," p. 211, says that the plant is indigenous to the Philippine Islands, but that the Indians cultivate it. Merrill, however, writes on the label attached to his specimen 3800 from Manila (December 17th, 1903), "Cultivated only in Philippines, Blanco to contrary notwithstanding, and now rarely found." The same authority, in his recent "Flora of Manila," p. 364, states that the tree is rarely cultivated and only of local occurrence in the Philippines, adding that it was "introduced from Mexico at an early date, and apparently formerly much more common than now." Hiern in his monograph of the Ebenaceae follows Blanco and quotes the following:- " Philippines, Sonnerat, Blanco; Celebes, Jacquin; Amboina, Rumph.," adding, "Cultivated in Mauritius, at Calcutta, and Malacca, Maingay 975. Occurs also in cultivated places in tropical America, perhaps introduced." As we have pointed out, Merrill states that Blanco is wrong, while Koorders does not record the plant from Java or Celebes. We may note that Jacquin in "Hort. Schoen.," vol. iii. p. 35, is not very explicit as to the locality of the plant, saying only, "Crescit in insula Celebes. Culta in insula Mauritii." Rumphius is more definite; he says that it is "rare in Amboina, only one here and there in the region of Hitoe and in Banda, but frequent in Ceram and certainly in Bonoa; likewise in Sumatra round Jamby." From this it would appear that the tree is a native of these islands. The plant, however, which Rumphius figures and calls "Hebenaster" is reduced by Miquel in his "Flora van Nederlandsch Indië," vol. ii. p.1047, to D.Ebenum Retz. (which, by the way, should be $D$. Ebenum Koen., as Koenig described it in

(3706.) Wt. 225-595. 1,125. 3/15. J. T. \& S. G. 14. 
1776 and Retzius in 1789). Further, Miquel makes no mention of D. Ebenaster. Rumphius gives various vernacular terms applied to "Hebenaster" by the natives of the different islandsa few of these being Ahuelloe, Gamomong, Lolin, Lorin, all of which, according to Filet, are popular names for D. Ebenum. Lastly, if we take Rumphius' description and figure, we find that they agree more closely with $D$. Ebenum than with $D$. Ebenaster, notably in the leaves being acute at the apex and having on their under surface a few hairs at the bases of the nerves. It is evident, therefore, that Rumphius' plant is $D$. Ebenum, Koen.

With regard to Malacca, Maingay's specimen 975 bears a note in pencil to the effect that the plant is cultivated, while Loher 407 is from the Botanic Garden at Manila.

The bulk of the evidence, then, points to Diospyros Ebenaster being introduced into the East Indies. The earliest record of the plant is apparently that of Sonnerat, who found the tree on his visit to the Philippines, and described and figured it in his "Voyage à la Nouvelle Guinée " (pp. 45-46, tt. 14-16), published in 1776. That the tree in all probability was introduced before this date is credible, for the Philippines were kept in close touch with Mexico and the West Indies by means of the Spanish galleons which.plied the Pacific regularly from the late 16th or early 17th century up till the beginning of the 19th century. This period was one of great commercial activity among the Spaniards, and various authorities tell us that many trees and shrubs (mostly of some economic value) were introduced into the East Indies from Mexico and the Spanish islands of the West.

Urban in the "Symbolae Antillanae," iv. p. 485, is apparently convinced that the tree is a native of the West Indies, and gives its locality in the Antilles as "Prope Toa-Alta in montibus; Stahl 872." The fact that the plant was found growing in the mountains would appear to be conclusive. Urban also gives the following localities, "Cuba, Monserrat, Guadeloupe, Dominica, Mexico, Brasilia, insulae Malayanae," and adds on the authority of Duss that the tree is certainly indigenous to the Antilles since it was found growing in the woods in the interior of Guadeloupe. Duss' discoveries leave us in no doubt whatever, for he found the tree in various wild places. His own words are, "Assez abondant dans les bois du massif du Houëlmont, plus rare dans les bois des Bains-Jaunes et du Gommier; se rencontre aussi dans les hauteurs de Bouillante (Trou au Trois-Diables), et dans les bois inférieurs de la Pointe-Noire (No. 25r3): Il n'est pas à la Martinique."

Unfortunately, the American material of Diospyros Ebenaster in the Kew Herbarium is somewhat limited. Of the specimens from Mexico, Botteri 909 from Orizaba would appear to indicate that the tree is native there-but Bourgeau's specimens 1823 and 2327 from the valley of Cordoba are cultivated (on the authority of Hiern). Urbina, in his catalogue of Mexican plants, makes no mention of the tree, while Sessé and Mociño in the "Plantae Novae Hispaniae" (2nd ed.), p.166, and also in the "Flora Mexicana" (2nd ed.), p. 237, speak of it as Diospyros Tlilzapotl, and 
give its habitat as "in calidis Novae Hispaniae regionibus." Their description of the plant agrees with that of $D$. Ebenaster. Ramirez, in his "Sinonimia de las Plantas Mexicanas," p. 94, gives the vernacular name as "Tlilzápotl" and the locality as Morelos. Hernandez (who explored Mexico between 1571 and 1577) on two separate occasions in his "Opera" (p. 129 and p. 164 of vol. i.), speaks of the medicinal properties of the tree, but the figure of " Tlilzápotl " in Recchus' edition of Hernandez, p. 430 , does not agree with $D$. Ebenaster in that the fruits are somewhat pointed at the apex. Hemsley ("Biologia Cent. Americana," vol. ii. p. 300), states that the tree is only found in cultivated places, and is of the opinion that it has been introduced.

From Brazil, Glaziou 7747 is cultivated, and it may be noted that Martius in the "Flora Brasiliensis" is very vague as to the exact locality of $D$. brasiliensis ( $=D$. Ebenaster according to Hiern), only stating that it grows in the interior! Part at least, if not all, of the material from Dominica is from the Botanic Gardens, so that the tree may be introduced there; but the fact that it is popularly called "bambarra" by the natives in the island suggests that it may be indigenous and more common than our specimens indicate.

From the evidence we have collected, therefore, we must conclude that the natural habitat of Diospyros Ebenaster, Retz., is in the West Indies. With regard to Mexico, it is evident from the references quoted above that the tree must have existed there for at least three centuries. As the native name "Tlilzápotl " is merely the Indian rendering of the Spanish "Zapote negro," it is very probable that the tree was introduced into Mexico by the Spaniards, but if this be correct, the introduction must have taken place at a very early date.

It may be fitting to conclude these remarks with a note on the narcotic or poisonous properties of the fruit of this interesting tree. The fruit is large, reaching three inches in diameter; it is globose in shape and of an olive- or yellowish-green colour, while the pulp is dark. The fruit (including the seeds) is pounded and thrown into the rivers by the natives of the West Indies in order to stupefy the fish and so facilitate their capture. Some observers-Greshoff being the most recent of themdeclare that the fish are killed by partaking of this fruit.

\section{V.-THE SOUTH AFRICAN SECTIONS OF LORANTHUS.}

T. A. SPRAGUE.

The genus Loranthus* has been divided into a large number of groups, which have been treated by Van Tieghem as independent genera, by Engler as subgenera, sections and series.†

* As defined in Engler \& Prantl, Nat. Pflanzenfam, vol. iii., 1, p. 183.

† See Kew Bull. 1914, pp. 362-367. 